\title{
On Dokuzuncu Yüzyılda Doğu Akdeniz Liman Kentinin Yapısı
}

\section{Urban Structure of the Eastern Mediterranean Port City in Nineteenth Century}

D Tülin Selvi Ünlü

Mersin Üniversitesi, Akdeniz Kent Araştırmaları Merkezi, Mersin

\section{ÖZ}

Doğu Akdeniz liman kentlerinin pek çoğunun gelişiminde ve bazılarının da bir iskeleden liman kentine evrilmesinde, on dokuzuncu yüzyılın özellikle Doğu Akdeniz'de yarattığı üretim biçim ve ilişkilerindeki değişimin etkisini yadsımak olanaksızdır. Ancak öte yandan, söz konusu kentlerin, ortak bazı yapısal özellikler taşıdıkları ve sahip oldukları liman olanakları ile deniz üzerinden kurulan yeni bir ilişki ağı ve biçimini üreten birer aktör oldukları görülür. Peki, özellikle on dokuzuncu yüzyılın ikinci yarısından itibaren, Doğu Akdeniz'de artan ticaret ve nüfus hareketlerinin birer odak noktası olan bu kentlerin, sahip oldukları benzer yapısal özellikler, yirminci yüzyıla kadarki süreçte nasıl bir gelişim ve değişim geçirmiştir? Bu soru çerçevesinde, söz konusu kentlere ilişkin çeşitli çalışmalar incelenerek, Doğu Akdeniz liman kentlerinin ortak yapısal özellikleri ve on dokuzuncu yüzyılda geçirdikleri benzerlik gösteren mekânsal değişim ele alınmıştır.

Anahtar sözcükler: Doğu Akdeniz liman kenti; mekansal yapı ve gelişim; on dokuzuncu yüzyll.

\begin{abstract}
The Mediterranean attracted researchers as a field of study due to its existence as the material space of reciprocal and regenerative relationships between human beings, their culture and nature, land and sea. The port cities in the Eastern Mediterranean region had been mostly discussed in relation to their economic relationships, owing to their geographic location, and to globalization processes. In this study, the spatial structure of the Eastern Mediterranean port cities in the nineteenth century is discussed. Accordingly hereby, the shaping of the urban structure of the Eastern Mediterranean port cities is discussed in the study with reference to the components of urban structure throughout different examples. Since most of the previous studies on Mediterranean port cities focus on their economical and social aspects, this study aims to contribute to these studies with a spatial perspective.
\end{abstract}

Keywords: Eastern Mediterranean port cities; urban structure and development; nineteenth century. 
Günümüzde "liman kenti” olarak adlandırılan, ancak birbirinden oldukça farklı özellikler gösteren kentler görmek olanaklıdır. Örneğin İzmir'in kentsel dokusu, Londra'dan, Manchester'dan ve hatta İstanbul'dan farklıyken, Beyrut'a, Selanik'e ya da İskenderiye'ye daha çok benzer (Kolluoğlu Kırlı 2007, 22 I). Doğu Akdeniz liman kentlerine ilişkin çalışmaların bazıları, söz konusu benzerliklerin bu kentlere ilişkin ortak bir yargıya varmaya olanak sağlayamayacağını öne sürerken bazıları ise söz konusu kentlerin pek çok açıdan ortaklıklarına vurgu yapmıştır (Selvi Ünlü 2016). Ancak, iki farklı sonuca ulaşsa da söz konusu çalışmalarda, Akdeniz'in doğusundaki liman kentlerinin gelişimlerinde benzer süreç ve aktörlerin etkili olduğu dikkat çeker. Bu koşulları üreten, on dokuzuncu yüzyılda Akdeniz'in özellikle doğusunda yaşanan yapısal değişim ve modernleşme süreçleridir. Bu süreçler, söz konusu kentlerin kıyıdaki konumları ve art alanları ile ilişki içinde gelişen uluslararası ticari ilişkilerin karşılıklı olarak birbirini ürettiği, toplumsal yapı ve kentsel mekandaki değişimleri kapsar.

On dokuzuncu yüzyılın ilk çeyreğinden itibaren sanayi alanındaki gelişmelerle birlikte Avrupa ülkeleri yeni üretim biçim ve ilişkileri geliştirmeye başlamış özellikle Sanayi Devrimi'ni gerçekleştiren başta İngiltere olmak üzere Fransa ve Almanya gibi ülkeler, nüfusu hızla artan kentin sorunlarıyla yüz yüze kalmışlardır. Batıda sanayi kentinin sorunlarına çözüm arayışının sürdüğü bu dönem aynı zamanda, sanayileşmiş söz konusu kapitalist ülkelerin Akdeniz'in doğusundaki coğrafyada sömürgeci bir yaklaşımla kıyasıya rekabet ettikleri bir dönemdir.

Batının makineleşen ve hızla ilerleyen sanayisi için gereksinim duyduğu ucuz hammadde ve aynı zamanda yeni pazar arayışı, kapitalist ülkelerin en kolay ve hızlı eriştikleri liman kentleri için yeni bir dönemi beraberinde getirmiştir. Sanayi devriminin sağladığı buhar teknolojisi ile denizyolu ulaşımında ve taşımacılığındaki yeni olanaklar, özellikle tarımsal üretimin egemen olduğu Akdeniz'in doğusundaki coğrafyayı oldukça çekici kılmıştır. Böylece, Doğu Akdeniz kıyılarında, bazıları antik dönemden itibaren kesintisiz olarak birer liman olan ve bazıları ise on dokuzuncu yüzyılın söz konusu gelişmeleri sonucu neredeyse yoktan var olan çok sayıda liman kenti önemli değişimler geçirmiştir.

Doğu Akdeniz liman kentinin gelişiminde, iktisadi ve toplumsal yapıda yaşanan değişim ve gelişmeler ile bu değişim ve gelişmelerle ilişki içindeki mekansal yapının belirleyici rolü dikkat çeker. İktisadi ve toplumsal yapıdaki gelişmeler ve modernleşme süreçleri, yere özgü farklılıklarına karşın bu kentlere, “liman kenti” ortak kimliği kazandıran koşulları üretmiştir. Bu benzer süreç ve koşulların izleri, çeşitlilik gösteren ve yerelin kendine özgü bağlamı içinde, her birine ayrı bir karakter kazandıran, Doğu Akdeniz liman kentinin mekansal yapısında somut olarak görülebilir. En başta bu kentler, deniz kıyısında ve çoğunlukla doğal liman oluşturan bir körfeze sahip konumları, art alanındaki verimli tarımsal üretim bölgeleri ve genellikle antik dönemden itibaren var olan liman işlevi gibi çeşitli yapısal özellikleri ile iç kesimlerdeki kentlerden farklılaştıkları gibi, içinde yer aldıkları coğrafi bağlam ve toplumsal yapıyla birlikte birbirlerinden de farklılaşmışlardır. Ancak, denizle kurulan doğrudan ilişkiyle bu kentlerin hemen hepsinde, mekansal yapı denizi referans alan bir kurguyla gelişmiştir. Söz konusu ilişkinin somut fiziksel öğesi ise kıyıdaki iskeleler ya da varsa limandır.

\section{Liman İşlevi ve Kentsel Mekanın Gelişimi}

Bu kentlerin benzer mekansal özelliklerinin başında, deniz (liman) ile kent arasındaki ilişki ve bunun ürettiği mekansal kurgu gelir (Soffer ve Stern 1986, 103). Özveren'e göre (1994, 77), Beyrut'u, Halep, Şam, Bağdad ve Kahire gibi kentlerden farklılaştıran, kıyı şeridine uzanan ve deniz yöneliminin "panaromik manzarası”nı oluşturan mekansal yapısıdır. Öyle ki, pek çok gezgin ya da araştırmacı, bu kentleri anlatmaya kentin içinden değil, denizden görünümü ile başlamış, kenti denizle ilişkisi üzerinden değerlendirmiştir. Örneğin Gounaris (1994, 103), kente gelen tüm yabancı gözlemcilerin, denizden bakarak, Bizans kiliseleri, minareleri, Roma anıtları, kent surları, kuleleri ve kırmızı kiremitli çatılarıyla Selanik'i, hoş bir tablo olarak gördüklerini dile getirmiştir.

Denizi esas alan mekansal gelişimde belirleyici işlev ve aynı zamanda yapı, liman olmuştur. Söz konusu kentler genellikle, coğrafyanın sunduğu olanaklarla, doğal bir körfezde, on dokuzuncu yüzyıldan çok daha erken dönemlerde gelişmeye başlamış kentlerdir. Örneğin Hayfa, İsrail kıyısının en büyük körfezinde gelişirken, Yafa ise kıyıdaki küçük bir tepenin üzerinde, oldukça korunaklı bir burunda yer almıştır (Amiran ve Shahar 196I, 355). Sahip oldukları bu coğrafi konum onlara doğal bir liman işlevi kazandırmıştır.

Dolayısıyla liman, söz konusu kentlerin yapısal olarak sahip oldukları bir işlevken aynı zamanda, on dokuzuncu yüzyılda gelişen deniz ticaretinin bir sonucu olarak, artan ticari etkinlikle birlikte bu kentlerin gelişmeleri için temel ivmeyi vermiştir ve kentin mekansal gelişiminin başlangıç noktası da liman ve çevresindeki çekirdektir. Örneğin Beyrut, on dokuzuncu yüzyılda bir liman olarak gelişen ticari etkinliğine paralel bir kentsel gelişme göstermiştir. Özellikle ipek ticareti ağındaki önemli konumuyla kent, bu alanda 1850'li yıllardan sonra yapılan yatırımlarla önemli bir sıçrama yaşamış ve limanı, demiryolu bağlantıları, elektrikli tramvayı, okulları, hastaneleri ile fiziksel olarak dikkat çekici bir değişim geçirmiştir (Özveren 1994, 84, 85). Benzer biçimde İzmir de bu dönemde, Anadolu'nun batıya en yakın limanı olarak Osmanlı'nın Avrupa ülkelerine açılan kapısı olmuştur. Kent, iç bölgelerdeki tarımsal ürünün aktarılmasındaki işleviyle birlikte büyük bir değişim yaşamış, bu değişim İzmir'i, yalnızca Doğu Akdeniz'de değil, tüm Akde- 
niz içinde en önemli liman kentlerinden biri haline getirmiştir (Frangakis-Syrett 200I, 23). Liman işlevi ile kentsel mekanın gelişimi arasındaki ilişki İzmir örneğinde oldukça somut biçimde görülmektedir. Bilsel $(2000,36)$, on dokuzuncu yüzyılda gerçekleştirilen projeler içinde, İzmir kentinin mekansal yapısı üzerinde en büyük etkiyi, liman ve rıhtım projelerinin yarattığını, söz konusu projelerin kentin deniz cephesini tümüyle değiştirdiğini ifade etmiştir.

İskenderiye için de liman ve kentsel gelişim arasındaki ilişki benzer biçimde ilerlemiştir. On dokuzuncu yüzyıl öncesinde küçük bir köy olan yerleşim, özellikle 1850'li yıllardan itibaren pamuk ticaretinde, iç bölgeleri dışa bağlayan önemli bir liman haline gelmiştir (Ilbert vd. 2006a; Abdel-Salam 1995, 183; Barak 2009, 189). Limanda artan ticari etkinlik kentsel mekanın gelişiminde de etkili olmuştur. Barak (2009, 189), on dokuzuncu yüzyılda, kentteki yolların yazın toz ve kışın da çamur içinde olması ve sokaklarda sıklıkla çukurlar ve tümseklerle karşılaşılmasının, yalnızca kentliler için değil, asfaltsız, inişli çıkışı sokaklardan limana pamuk ve diğer malları ulaştırmaya çalışan tüccarlar açısından da önemli bir sorun ve maliyet oluşturduğunu belirtmiştir. Bu sorunun çözümü için kentte ihracatçılar tarafından kurulan bir komisyonla, limandan kentin diğer bölgelerine ulaşan yol kaplamaları ve kaldırımlar yapılmış, 1890 yılında İskenderiye Belediyesi'ne dahil olan bu komisyon, kentteki tüm sokakların planlanmasından sorumlu olmuştur (Barak, 2009, 190). Ayrıca, ağırlıklı olarak kentteki yabancılar ve konsolosluk temsilcilerinden oluşan bir yapı ve yol komisyonu kurulmuş ve mekansal gelişim için çeşitli politikalar üretilmiştir (Abdel-Salam, 1995, I8I). Abulafia'a göre $(2012,65 \mathrm{I})$ İskenderiye, yeni limanın inşası, sahil yolunun (korniş) yapımı ve yeni konut ve iş yerlerinin inşa edildiği geniş caddelerin açılmasıyla modern bir biçim almaya başlamıştır.

Selanik ise tıpkı İzmir ve İskenderiye gibi 1900'lere doğru, buharlı gemilerin yanaşabileceği bir limanı, bankaları, hastaneleri, fabrikaları ve yeni taş binaları ile Anastassiadou'ya göre $(2014,85)$ "egzotizm heveslilerini hayal kırıklığına uğratacak modern bir şehir" görünümüne kavuşmuştur. Doğu Akdeniz liman kentleri ağındaki, Beyrut, İzmir, İskenderiye, Selanik gibi kapasite ve ölçek açısından ilk sırada yer alan kentlerin dışında, Yafa, Mersin, Kavala (Arslan 2009), Volos ve Patras gibi daha küçük ölçekli liman kentlerinde de, liman işlevine dayalı benzer kentsel gelişmeler yaşanmıştır. Örneğin Kudüs'ün denize ana çıkış kapısı olan Yafa, yalnızca Akdeniz'den iç kesimlere yönelik transit ticaretle değil, Osmanlı topraklarına ve Batı Avrupa'ya kadar gönderilen ünlü portakalları sayesinde bölgede önemli bir merkez haline gelmiştir. Limandaki ticari etkinlikle birlikte bölge içinde bir çekim noktası haline gelmesi
Yafa'yı Yahudi, Hıristiyan ve Müslüman nüfusun birlikte yaşadığı bir yerleşim haline getirmiş, artan nüfusla kentin çevresinde banliyöler oluşmaya başlamıştır (Abulafia, 20I2, 660, 66I).'

On dokuzuncu yüzyılın öncesinde, alçak kalesi, limanının büyüklüğü, yapıları ve ekonomik önemi açısından çok dikkat çekmeyen bir yerleşim olan Volos ise on dokuzuncu yüzyıldan itibaren, eteklerinde yer aldığı Pelion Dağı'ndan gelen tüccarların ilgisi ve sahip olduğu doğal limanı ile bölgede ticari bir merkez olarak gelişmiştir (Dimoglou ve Mourtzoukos 2006, II). Kale içindeki yerleşimde, deniz-dağ ilişkisini kuran ana eksen ve buna bağlanan sokakları ile Osmanlı kent dokusunu izlemek olanaklıdır (Dimoglou 2003, 6I). Kale içindeki bu yerleşim, Teselya Ovası'ndaki tahıl üretimi nedeniyle giderek önem kazanmış, on yedinci yüzyıldan itibaren, kalenin dışında deniz kıyısında, tahıl ve diğer tarımsal ürünlerin ithalatı için yeni bir bölge gelişmiştir. Burası, gümrük, dükkanlar, hanlar, atölyeler ve depoları ile kentin en işlek bölgesidir (Paliouras 2004, 78). Zamanla kale dışında gelişen yeni şehir, ızgara dokuyu esas alan, tüccarların gereksinimlerini karşılamaya yönelik bir arazi bölümlemesi ile şekillenmiştir (Hastaoglou-Martinidis 2004, 48). Dolayısıyla Volos'ta da, mekansal gelişim limanda artan ticari etkinlikle birlikte ve limanla ilişki içinde ve yine ticari etkinliğin gereksinimleri doğrultusunda şekillenmiştir.

Volos gibi Patras da, Osmanlı egemenliği döneminde, kale ve çevresinde kendiliğinden gelişen, dar sokakları ve saçaklı evleriyle küçük bir Osmanlı kentiyken, "siyah altın” denilen kuş üzümüne dayalı ticaretin kıyıda yarattığı hareketlilikle bir liman kentine doğru evrilmiştir. Kentte, tarımsal üretime dayalı ekonomiden deniz ticaretine dayalı ekonomiye geçildiği bu süreçte, sosyo-ekonomik yapı değişmeye başlamış, eski toprak sahibi, köylü ve çiftçilerin yerini, yavaş yavaş tüccar ve girişimciler almıştır (Bakounakis 2005, 249). Yunanistan'dan ve dışarıdan gelen Rum tüccar ve iş adamlarının yanı sıra, ticaretin inceliklerini bilen ve yeni pazar alanları arayan çok sayıda yabancı girişimci kente yerleşmiştir. Patras'ın bu yeni sakinleri, yerleşime yakın noktalarda üzüm bağları satın almış ve özellikle kıyı şeridinde yerleşmeye başlamışlardır (Chatziioannou 20I5, 19, 20). Böylece geçmişten beri, kale ve çevresinde, denizden kopuk olarak gelişen kent, limanda artan ticari etkinlikle birlikte deniz kıyısında eskisinden oldukça farklı bir görünüm sergilemeye başlamıştır (Selvi Ünlü 2016, I82).

Patras ve Volos'a benzer biçimde, Kavala da başlangıçta bir dağın üzerinde kurulmuş, Penaje Dağı'nın eteklerindeki limanıyla, çevresindeki ovalarda süren hayvancılık, tarım gibi faaliyetlerin yanı sıra balıkçılığın da olduğu bir yerleşimdir (Arslan, 2009, 43; Yıldız, 2018, 218). Doğu Makedonya'nın ana limanı

Liman işlevinin kent için önemi, kentin kuzeyinde inşa edilen yeni limanın Tel Aviv’e hizmet etmesi sonucu Yafa'nın bir anlamda sonu olmasından anlaşılmaktadır. Abulafia'ya göre $(2012,661)$, söz konusu yeni limanın inşası Yafa açısından en önemli gelişmelerden biri olmuş, I935 yılında Yafa Limanı'ndaki ticari faaliyet neredeyse yarı yarıya azalmıştır. Öte yandan, yine kentsel gelişim ve liman ilişkisini ortaya koyması açısından Tel Aviv de bir başka örnek olarak belirmektedir. Söz konusu limanın inşasıyla Tel Aviv, özellikle İskoç mimar Patrick Geddes'in kent-deniz ilişkisini geliştirmeyi hedefleyen planının da katkısıyla, kent merkezindeki Bauhaus tarzı yapıları ve zengin kent sakinlerinin modern Batılı kültürün taşıyıcıları olarak görülme isteklerini yansıtan yeni şehirle hızla gelişmiştir (Abulafia, 20।2, 662). 
olan Kavala, Egnatia Yolu'nun (Via Egnetia) önemli istasyonlarından biridir (Lalenis and Samourkasidou, 2013, 209). Kayalık bir burundaki korunaklı konumuyla on yedinci yüzyıldan itibaren Osmanlı'nın dikkatini çeken Kavala, kalenin onarılması, su kemerlerinin inşası gibi yatırımların yanı sıra, tıpkı Volos ve Patras'ta olduğu gibi kale dışında, kıyıda ticari etkinliğin başladığı bir yerleşim haline gelmiştir. On dokuzuncu yüzyılda, kalenin eteklerinden başlayan ana cadde boyunca devam eden evleri ve bakımlı sokaklarıyla Kavala, tıpkı Selanik'te olduğu gibi kale dışındaki yapılaşma ile gelişmiş ve kalenin batı ve doğusunda yeni mahalleler oluşmuştur (Yıldız, 2018, 218-220; Arslan, 2009, 49). Özellikle 1839-1913 yılları arasında, bölgesel bir ihraç limanı haline gelen Kavala, kentsel olarak da hızlı bir gelişim göstermiştir (Stergiopoulos, 2016, 95). Limandaki tütün ihracatına dayalı olarak, kentte çok sayıda tütün deposu inşa edilmiştir ve söz konusu yapılardan bazıları günümüzde de kentin önemli bir simgesi olarak varlığını sürdürmektedir (Rentetzi, 2008, 64). İzmir'de olduğu gibi Kavala'da da kent, denizle doğrudan ilişkili olarak, bir amfitiyatro gibi koyu çevrelemiş, yerleşim topoğrafyaya uyumlu olarak limana hakim ve bütün koyu kucaklar biçimde şekillenmiştir.

Limandaki ticari etkinlikle birlikte, çeşitli benzer mekansal yapı bileşenlerinin kendini gösterdiği bu kentlerde, deniz ticareti ile bağlantılı olarak ticari etkinliğin gerçekleştiği yer, temel olarak kıyı şeridi olmuştur. Kıyıdaki iskele ya da iskeleler, bu kentlerin mekansal gelişiminde belirleyici ortak fiziksel öğeler olmuş, örneğin İzmir'de, farklı firmaların iskeleleri kıyı boyunca sıralanmıştır (Bilsel 2009, I44). Benzer biçimde, İskenderiye'de de, ilk tren garının inşa edildiği, ihracat teknelerinin yanaştıkları Soğan Limanı, çok sayıda ihracat firmasının ambar binaları ve depolarıyla dolmuştur (Ilbert 2006c, 21, 22). Söz konusu gelişmeler ise bu kentlerin mekansal gelişiminde denizin belirleyici olduğu, liman ve denizle doğrudan ilişkiyi esas alan bir mekansal kurguya işaret etmektedir.

$\mathrm{Bu}$ kentlerdeki temel ortak mekansal bileşen olarak, kentin denizle ilişkisini kuran iskelelerin yanı sıra, özellikle uluslararası ticaretin yoğun olarak kendini gösterdiği on dokuzuncu yüzyılın ikinci yarısından itibaren, gümrük binası, deniz feneri, mendirek, dalgakıran gibi liman işlevini güçlendirmeye dayalı yapılar inşa edilmiştir. Örneğin İzmir'de, I880 yılında yapılan yeni liman ve limanı, dışarıdan gelecek olumsuz etkilere karşı korumaya yönelik inşa edilen dalgakıranın yanı sıra yeni bir gümrük binası yapılmıştır (Frangakis-Syrett 200।, 23-26). Bu alanda, uluslararası ticaretin göstergesi olan denizcilik şirketleri, sigorta acenteleri, uluslararası şirketlerin temsilcilikleri yer almaya başlarken, rıhtımda Punto İstasyonu (günümüzdeki Alsancak İstasyonu) ile Konak arasında bir tramvay hattı işletmeye açılmıştır (Bilsel 2008, I54). Dolayısıyla günümüzde Kordon olarak adlandırılan kıyı şeridinin şekillenmesi, kentin mekansal organizasyonunda önemli rol oynamıştır ${ }^{2}$ (Zandi-Sayek 2012, I15-149).

İzmir limanı inşaatını üstlenen şirket, Selanik'te de benzer bir projeyi gerçekleştirmiştir. 1880 yılında, kent surlarının yıkılarak ortaçağ kentinin denize açılması hedefi doğrultusunda inşa edilen ve İzmir'de olduğu gibi kenti boydan boya kat eden ve limanı, kent surlarının dışında, yeni kurulan konut bölgesine bağlayan rıhtım tamamlanmıştır. Dolgu ile elde edilen alanda gümrük binaları, çeşitli idari yapılar inşa edilirken, kordon niteliği gösteren alan, aynı zamanda kentliler için bir yürüyüş yolu haline gelmiştir (Yeralympos 1996, 63).

Benzer biçimde İskenderiye'de de, limandaki hareketliliğe bağlı olarak, kentin denize dönük konumunu güçlendirmek ve modernizasyonu için 1810 yılı ile 1839 arasında pek çok yatırım yapılmıştır (Ilbert 2006b, I I). I828-1833 yılları arasında yeni liman ve mühimmat deposu inşa edilmiş ve Batı limanında yeni bir donanma kurulmuştur (Abdel-Salam 1995, 179). 1870 yılında liman tamamlanmış ve 1905 yılından itibaren Korniş'in başlangıcını oluşturan rıhtım inşa edilmiştir (Ilbert 2006b, 14).

Volos'ta ise Avrupa'nın artan tahıl talebi, limana gelen gemi sayısını artırmış, başka yerleşimlerden gelen tüccarlar için de çekici bir hal alan kentte, 1873 yılında limanın geliştirilmesine yönelik olarak, kıyııı gelgitlerden koruyacak bir set çekilmesi ve mevcut ana iskelenin genişletilmesi gibi bazı düzenlemeler başlamıştır (Hastaoglou-Martinidis 2004, 53). Volos gibi Patras'ta da, on dokuzuncu yüzyılın ikinci yarısından itibaren, liman hizmetlerini iyileştiren yatırımlar yapılmaya başlanmış, I820'li yıllardan 1870'li yıllara kadar olan dönemde kent, deniz kıyısında gelişen yeni (aşă̆ı) şehir, yürüyüş yolları, düzgün sokakları, neoklasik tarzda yapılmış yeni konut, dükkan, depo ve kamusal yapıları, meydanları ile özellikle ticaret burjuvazisi için oldukça çekici bir görünüm kazanmıştır (MP 20|4, I44).

Artan ticari etkinliğin talepleriyle birlikte, liman işlevinin güçlendirilmesine yönelik olarak söz konusu kentlerde yapılan tüm bu fiziksel düzenlemelerin yanı sıra kentsel mekanda değişim yaratan bir diğer gelişme ise kıyı dolguları olmuştur. Söz konusu kentlerin pek çoğunda, ticari etkinliğin ana mekanı olarak giderek yoğunlaşan ve değer kazanan kıyı kesimi, zaman içinde yetersiz hale gelmiş ve gerekli yeni alanın kazanılması için denize dolgu yapılmıştır.

Örneğin İzmir'de, 1830’lu yıllarda, kıyı çizgisinden deniz yönüne doğru 15 metrelik bir şerit satışa çıkarılmış ve satılan bu alanın doldurulması şart koşulmuştur. İlk aşamada, gelir etme amacı ve daha sonraki süreçte ise kentin kıyı kesiminin düzenlenmesini amaçlayan uygulamalarla, kentin doğal kıyı çizgisi büyük ölçüde değişime uğramıştır (Beyru 20I I, 349, 350).

Zandi-Sayek, kıyı şeridindeki gelişmelerin, kentin yalnızca mekansal gelişiminde değil, toplumsal yaşamın gelişiminde de etkili olduğunu, kentteki kamusal yaşamın (public sphere), kentin modern altyapısının inşası ve fiziksel biçimlenişiyle birlikte geliştiğini vurgulamaktadır. Bknz. Zandi-Sayek, $2012,148$. 
İzmir'de olduğu gibi, |870-187| yıllarında, yıkılan kale surlarının taşlarıyla Selanik'te ve 1842-1843 yıllarında da Volos'ta yapılan deniz dolgusu, bu kentlerdeki kıyı çizgisini değiştirmiş ve kıyıda yeni yapı adaları inşa edilmiştir (Hastaoglou-Martinidis 2007, 39).

Öte yandan, limanlar ve onunla birlikte inşa edilen ilişkili yapı ve kullanımlar, Doğu Akdeniz liman kentinde benzer fiziksel değişimlere yol açarken, limanın inşası da başı başına söz konusu kentlerdeki ortak deneyimlerden biri olmuştur. Bu dönemde özellikle Fransız müteahhit şirketlerinin tekelinde olan liman inşaatlarında, çoğu Süveyş Kanalı'nın yapımına katılmış ve Akdeniz'i dolaşarak, sahip oldukları teknik bilgiyi farklı kentlere taşıyan liman mühendisleri, hükümetlere ya da şirketlere, modern limanların planlanması ve inşaat işinin yönetiminde hizmet sunmuşlardır. Örneğin, Aguste Stoeklin, İskenderiye ve Beyrtut'ta, Hilarion Pascal İstanbul, Selanik, Varna, Patras'ta, Adolphe Guérard Selanik ve İstanbul limanlarında teknik danışmanlık yapmış ve Yafa planını hazırlamış, Eduard Quellenec İskenderiye, Pire ve birçok diğer Yunan kenti limanı için projeler çizmiş, Polikarp Vitalis İzmir ve Selanik rıhtım projelerini hayata geçirmiştir (Hastaoglou-Martinidis 2010, I0I-2).

\section{Gelişen Ticaret ve Finans Sektörü ve Kentsel Mekanın Gelişimi}

Limandaki ticari etkinliğe dayalı gelişimleriyle bu kentlerde, ticari faaliyetin gerektirdiği çeşitli yeni kullanımların da kentsel mekanda yer almaya başladığı görülür. Örneğin İzmir'de, gelişen ticaretle birlikte, on dokuzuncu yüzyıl ortalarından itibaren, başta o dönemde bölgede yayılan ve birçok liman kentinde şube açan Osmanlı Bankası olmak üzere birçok yabancı banka şubesi hizmet vermeye başlamıştır. Öte yandan ticaret hacmindeki genişleme ile birlikte iletişim gereksinimi de artmış, kentte postaneler açılmıştır. Böylece, on dokuzuncu yüzyıl boyunca gelişen ticaret kentsel mekanda, postaneler, banka şubeleri ve ticaret hanları gibi uzmanlaşmış alanları beraberinde getirmiştir (Beyru 201 I, I53-156; Georgelin 2008, $55,56)$. Savaşlar ve kitlesel göçler gibi tarihsel nedenlerin yanı sıra ticaretteki söz konusu gelişmelerle birlikte İzmir'de özellikle I800'lü yılların sonundaki hızlı nüfus artışı, kentsel yerleşik alanın da hızla genişlemesiyle sonuçlanmış, özellikle limandan Punto'ya kadar uzanan sahil kesiminde hızlı bir nüfus artışı yaşanmıştır (Serçe 2010, 27).

İzmir'de olduğu gibi Selanik'de de, artan ticaretle birlikte finans sektöründeki gelişim, 1864 yılında Osmanlı Bankası ve I 888 yılında Selanik Bankası'nın birer şube açmasıyla kendini somut olarak göstermiştir. Kentte finans sektöründe gelişmenin mekana etkisi bununla da sınırı kalmamış, açılan bankaların ticari etkinlik ve sanayileşmenin gereksinim duyduğu finansmanı sunmasıyla, kentte pek çok yerel sanayi işletmesi kurulmuştur. Ticaret, finans ve sanayi alanındaki bu gelişmelerle birlik- te kentte önemli bir işçi sınıfı oluşmuş, on dokuzuncu yüzyıl sonunda Selanik, toplumsal sınıfların belirginleştiği bir kente dönüşmüştür (Akkaya 1998, 28, 29, 34; Akyalçın 20I5, 45). Bu süreçte kentte, geleneksel dini ve etnik ayrışmadan farklı, toplumsal ve iktisadi temelli bir sınıfsal farklılaşma şekillenmiştir. Din ve etnik kökenden bağımsız olan bu ayrışma, hem kentsel mekanda hem de sosyal yaşamda belirgin hale gelmiştir (Akyalçın Kaya 20। 5, 45, 46). Kentteki sınıfsal farklılaşma, özellikle I890'lı yıllardan itibaren, kentin geleneksel çekirdeği dışında, gelişen yeni konut alanlarında kendini somut olarak göstermiş, örneğin Rusya'dan kente göç eden düşük gelirli Yahudi nüfus için yapılan evlerin yanı sıra, kentin güneydoğusundaki sahil şeridi boyunca, varlıklı Yahudi, Hıristiyan ve Müslüman nüfus evleri inşa edilmiştir (Hastaoglou-Martinidis 1997, 494).

Ticari kapasitedeki gelişimin somut sonuçları, İzmir ve Selanik'te olduğu gibi Volos'ta da kendini göstermiş, 1882 yılında kentte, Bank Epirothessaly, Bank of Athens ve National Bank of Greece ve 1904 yılında, Londra, İskenderiye, Pire ve Patras gibi kentlerde şubesi olan Banque D'Athenes'in şubeleri açılmıştır. Finans sektöründeki gelişmeye paralel olarak, diğer pek çok liman kentinde olduğu gibi Volos da, yalnızca tarımsal ürünlerin ihracatının yapıldığı bir liman olmanın ötesine geçmiş ve kentte sanayi faaliyetleri başlamıştır. I883'ten itibaren fabrika ve imalathanelerin açılmasıyla Volos, bir ticaret kentinden sanayi kentine doğru evrilmeye başlamıştır. Öyle ki, 1910 sonunda, özellikle tütün ticaretindeki gelişmeyle birlikte sayıları yirmiyi geçen fabrika ve imalathaneleriyle kent, imalat sanayinde Larissa'yı geride bırakmıştır (Hastaoglou-Martinidis, 2007, 6I). Benzer biçimde, Patras'ta da, kuş üzümü pazarında belli bir istikrar sağlanması ve 1900 'lü yıllardan itibaren, şarap ve alkol imalathanelerinin kurulması, sülfür işleyen buharlı fabrikaların, zeytin ezimevi, sabun fabrikası, demir döküm atölyelerinin açılmasıyla, tarımsal üretim sanayileşmeye başlamıştır (Selvi Ünlü 2016, I4I).

Ticaretin gelişimi ve sanayi yatırımlarıyla birlikte bu kentlerdeki sermaye birikimi, yeni ve modern bir yaşam biçiminin gelişiminde etkili olmuş, kamusal ve özel, çok sayıda yeni yapı ve kurum kendini göstermeye başlamıştır. Örneğin Volos'ta, yeni toplumsal ve sosyal yaşamın somut birer yansıması olarak, çok sayıda gazete yayımlanmaya başlamış, özel ve kamuya ait eğitim kurumları açılmış ve her geçen gün kentin görünümü değişmiştir. Kentte 1883 yılında açılan hastane, 1903 yılında açılan yetimhane, 1909 yılında açılan konservatuar, 1907 yılında açılan kütüphane, 1908 yılında açılan Arkeoloji Müzesi ve Kız Okulu, I9II yılında açılan Ticaret Okulu gibi çok sayıda eğitim ve kültür yapısı, kentteki yaşamın birer parçası haline gelmiştir (Hastaoglou-Martinidis 2007, 6I).

Ticari etkinliğin artması, sanayinin gelişimi ve sermaye birikimiyle, yaşam biçimi ve kentsel mekanda gerçekleşen değişim, Volos'ta olduğu gibi İzmir'de de açık biçimde kendini göster- 
miştir. Serçe'ye göre $(2010,27)$ Osmanlı İmparatorluğu'nun diğer vilayetlerinden oldukça ileri durumda olan kentteki kültürel yaşamın bir göstergesi olarak Fransızca, Ermenice, Rumca, Türkçe yayımlanan gazeteler ve kentsel mekana eklenen basım atölyesi, matbaa gibi yeni yapılar bunun somut işaretleridir.

İnanç ve milliyete dayalı mahallelerden oluşan kentsel yapının, Doğu Akdeniz liman kentinde on dokuzuncu yüzyıl ortalarından itibaren sınıfsal farklılıklara göre biçimlenmeye başladığına ilişkin çarpıcı örneklerden bir diğeri ise İskenderiye'dir. Kentte, Yahudi cemaatine mensup hızla zenginleşen bir nüfus olduğu gibi aynı zamanda bir Yahudi proleteryası da yaşamaktadır (Hassoun 2006, 53). Nüfusun en yoğun olduğu Ramleh bölgesinde, yoksul Arap, Levanten, İtalyan ve Misırlılılar bir aradadır (Trimi 2006, 8I). Söz konusu sınıfsal farklılaşmanın İskenderiye'de kentsel mekana etkisi, kentin, limanla doğrudan ilişki içinde olan ve ticari kullanımların yoğun olarak yer seçtiği doğu bölgelerinin daha cazip kentsel alanlar olarak şekillenmesi, kuzey ve güney kesimlerin ise orta ve alt gelir gruplarının yaşadığı alanlar olarak gelişmesinde açıkça görülmektedir (Abdel-Salam 1995, 186).

İskenderiye ile karşılaştırılamayacak kadar küçük olsa da, kentsel mekandaki sınıfsal farklılaşmayı Kavala'da da görmek olanaklıdır. Selanik'teki kent surlarının yıkılmasıyla aynı tarihte, 1869 'da Kavala'da, deniz kıyısındaki surlar yıkılmaya başlamış, 1880'lerden sonra kent, yarımadanın doğusuna doğru gelişmiştir. On dokuzuncu yüzyılın ikinci yarısında, eski şehrin yerleşik bulunduğu yarımadanın dışında kıyı boyunca gelişen yeni yerleşim alanı, beyaz villaları, meydanları ve tütün işlenen mağazalarıyla kentin en canlı bölgesi haline gelmiştir (Arslan 2009, 16I).

Beyrut'ta da, on dokuzuncu yüzyılla birlikte, Avrupa ile ticaret yapan önemli bir grup oluşmuş ve bu grup kentteki burjuvazinin nüvesini oluşturmuştur. Söz konusu yerel burjuvazinin, kentin dışında yeni yaşam alanları inşa etmeye başlamasıyla, sınıfsal farklılaşma kentsel mekanda da belirginleştirmiştir (Barakat 2004, 486-487).

\section{Demografik Yapı ve Kentsel Mekanın Gelişimi}

On dokuzuncu yüzyılda Doğu Akdeniz liman kentleri, başta İngiltere ve Fransa olmak üzere Batı'nın sanayileşmiş ekonomilerinin, kapitalizmin temel mantığı çerçevesinde ve dönemin iktisadi koşulları içinde, en hızlı, kolay ve ekonomik biçimde nüfuz ettikleri yerler olmuştur. Keyder ve diğerleri (1994, I2I) ticaretin, kapitalist döngülere dahil olmanın temel mekanizması olduğunu ve ticari malların ancak liman kentleri aracıllğıyla siyasal sınırları aşabildiğini vurgulamıştır. Kapitalist ekonomi ile bütünleşme, Batı'nın etkisine daha açık olan Balkanlar ve Batı Anadolu'da başlamış ve azınlık-komprador bur- juvazinin etkisindeki liman kentleri, bu konjonktürde özel bir rol oynamışır (Reyhan 2008, 69).

Dolayısıyla, on dokuzuncu yüzyılda, kapitalist ilişkilere dahil olma sürecinde önem kazanan liman kentleri, tepeden yönetilen imparatorluk ticaret merkezlerinden farklılaşmış ve kapitalist ekonomiyle doğrudan bağlantılı olan ayrıcalıklı yerler olarak şekillenmiştir. Böylece bu kentler, dış ticaret ve yabancı/yerli yatırımlar ile birlikte, önemli nüfus hareketleriyle kapitalist ekonomiyle bütünleşme sürecini somut biçimde yaşamıştır (Keyder ve diğer. 1994, I21). Bu gelişmeler, ticaretle birlikte oluşan iş olanaklarına paralel olarak Doğu Akdeniz'deki pek çok liman kentinde nüfusun hızla artmasını beraberinde getirmiştir. Sundukları ekonomik fırsatlarla Akdeniz'in doğusundaki liman kentleri, Avrupa'dan, Akdeniz Havzasi'ndan ve iç kesimlerinden göçmenleri kendilerine çekmiştir (Keyder ve diğer. 1994, 138-144). Bu da, liman kentlerini farklılaştıran demografik çeşitliliği üretmiştir. Limandaki ticari etkinlik, finans ve sanayideki gelişmelerle birlikte, artan nüfus ve demografik yapıdaki çeşitlilik, Doğu Akdeniz liman kentleri için en karakteristik özelliklerden biri olmuştur (Hastaoglou-Martinidis 1997, 494). Söz konusu kentlerdeki demografik çeşitliliği, şark ticaret yıllıklarından izlemek olanaklıdır (Şekil I).

İzmir'de, kentin gelişen ekonomik yapısındaki dış ticaret ağırlığına paralel olarak, Rum ve Ermeni nüfus ile ticarete ve finans dünyasına yakınlıklarıyla Yahudiler, kentin en önemli demografik bileşenleri olmuştur (Alpaslan 2012, 29) ve on dokuzuncu yüzyılda, Müslüman, Yahudi, Katolik ve Ortodoks Hıristiyan gibi farklı dini inançlara sahip bu nüfus, kendi yaşam ritüelleriyle yaşamaktadır (Zandi-Sayek 20I2, I54). Birçok farkı toplumsal grubun bir arada yaşamasıyla, söz konusu kentlerde ortaklaşan kentsel kullanımlar olarak, kafe ve restoran gibi gelişen yeni yaşam kültürüne ait yapılar ve kamusal mekanlar da açılmıştır (Driessen 2005, 133-134).

Benzer biçimde, Selanik de, 1800 'lü yıllarda, nüfusunun neredeyse yarısı Yahudi olan, Müslüman Türkler, Ortodoks Rumlar, Dönmeler, Sirplar, Bulgarlar, Gregoryen Ermeniler gibi pek çok farklı grubun yaşadığı bir kenttir (Anastassiadou 20l4, 55). Tıpkı Selanik gibi, kurulduğu yıllardan itibaren önemli bir Yahudi nüfusu barındıran İskenderiye'de ise Fransızlar, İngilizler gibi Avrupalı toplulukların yanı sıra, Yunan, İtalyan, Ermeni nüfus birlikte yaşamaktadır (llbert vd. 2006a).

Selanik, İskenderiye, İzmir gibi Doğu Akdeniz'de birincil önem ve büyüklükteki liman kentleri ölçeğinde olmasa da, bir Doğu Akdeniz liman kenti olarak Yafa'da da, Müslüman nüfusun yanı sıra Rum, Ermeni, Yahudi, Latin, Maruni ve Katolik olmak üzere altı ayrı cemaat bulunmaktadır (Avcı 20I5, 40I). Patras'ta ağılıklı olarak Ortodoks Rumlar olmak üzere, Müslüman Türkler ve Yahudiler (Malcolm ve Frangakis-Syrett 1992, 85) yaşarken, Volos'ta, Müslüman Türk nüfusun yanı sıra, Ortodoks Rumlar, Katolik Avrupalılar ve Yahudiler (Hastaoglou- 

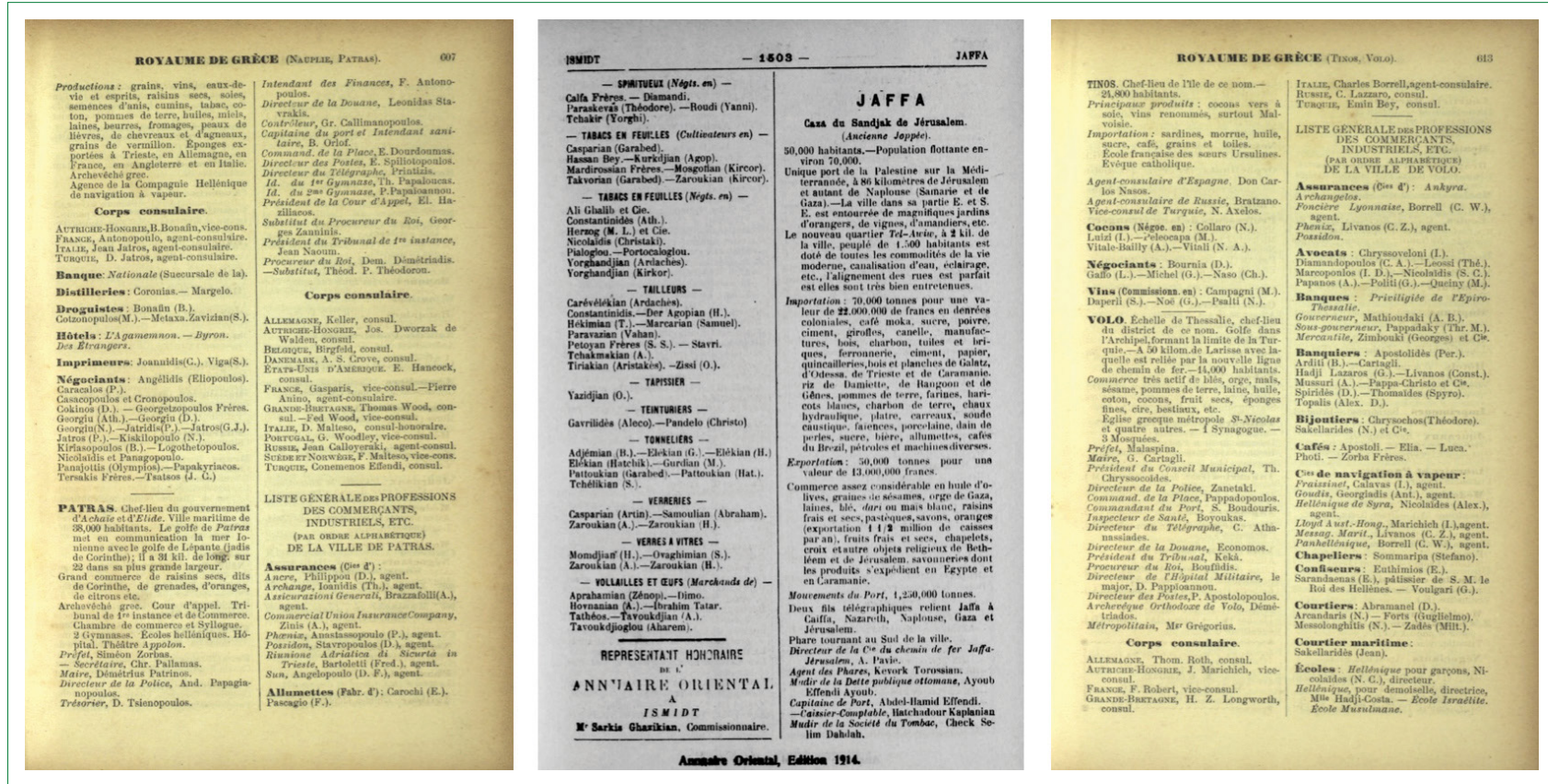

Şekil I. Patras, Yafa ve Volos Şark Ticaret Yıllıkları (Annuaire Oriental, SALT).

Martinidis 2007, 72) yaşamaktadır. Bu dönemde Mersin'de ise Avrupalı Katolikler (Levantenler), Ortodoks Araplar, Müslüman Türkler, Yahudiler, Ermeniler ile Maruni, Süryani, Keldani, Nusayri gibi gruplar bulunmaktadır (Selvi Ünlü 2007, 85-92).

Yine, Selanik ve İskenderiye gibi kuruluşundan itibaren Yahudi nüfusun yaşadığı bir diğer liman kenti Kavala'da da, nüfusun çeşitlilik gösteren yapısı dikkat çeker. Kentte Yahudi, Rum ve Müslüman Türk nüfus birlikte yaşamaktadır. Oranları zaman içinde değişiklik gösterse de, kentin on dokuzuncu yüzyıldaki hızlı gelişimiyle birlikte, Rum nüfus Müslüman Türk nüfusu geçmiş, bunun yanı sıra kentte küçük de olsa Ermeni ve Avrupalı nüfus grupları yaşamaya başlamıştır (Karagiannakidou ve Lykourinou 2005, 34, 35).

Çeşitlilik gösteren nüfusun kentsel mekandaki somut yansımalarından biri, farklı inançlara yönelik dini yapılar olarak belirmiştir. Örneğin Selanik'te, kilise, cami, sinagog mahalle yaşamının merkezinde yer almıs ve kentte nüfusun olduğu kadar kullanımın da çeşitliliğini yansıtan bu yapılardan bazıları, ibadetin yanı sıra okul ve hatta kimi zaman hastane olarak hizmet vermiştir. Üstelik, farklı dini inanca sahip kentliler bu hizmetten yararlanmıştır (Anastassiadou 20I4, 44-54). Anastassiadou (2014, 53), kentin her yerindeki varlıklarıyla, camiler, kiliseler ve sinagogların Selanik'in, dinlerin ve etnik grupların birbirine karışıı̆ı mekansal yapısına işaret ettiğini, Müslüman ve Hıristiyan nüfusun aynı dini mekanları kullanmasının kimseyi şaşırtmadığını belirtmiştir.

Farklı nüfus bileşenlerinin birlikte yaşamına bir başka örnek de İskenderiye'dir. llbert'e göre (2006b, 22), dar yolları ve çıkmaz sokaklarıla, camileri, cumbalı evleri, avlulu kervansarayları, gez- gin tüccarlara yönelik hanlarıly İskenderiye'de, Yunan, İtalyan, Sakızlı Yahudi ve Yerli Müslüman ve eski İskenderiyeli aileler bir arada yaşamaktadır. $1900^{\circ}$ lü yıllardan itibaren, kıyıda Korniş'in gelişimi ile kıyı kesiminin cazibesi artmış ve bu alanda farklı nüfus gruplarının okulları açımaya başlamışırı (llbert 2006b, 22).

Dolayısıyla, demografik yapıdaki çeşitlilik, kentsel mekanda dini yapıların yanı sıra eğitim kurumları ile de kendini göstermiş, farklı nüfus gruplarının kendi eğitim sistemlerine yönelik okullar hizmet vermeye başlamıştır. Örneğin Beyrut'ta, bir arada yaşayan Müslümanlar ve Hıristiyan nüfusla birlikte kentte yeni okullar açılmış, kentin fiziksel görünümü değişmeye başlamıştır (Barakat 2004, 486-487). Benzer biçimde İzmir'de de, hızla artan nüfus ve bu nüfusun çeşitliliği, kentsel mekana eklenen yeni eğitim kurumlarıyla somut olarak kendini göstermiştir. Öyle ki, eğitim kurumları açısından İmparatorluğun en önemli merkezlerinden biri olan kent, farklı nüfus gruplarına yönelik okullarıyla, yalnızca İzmir'e değil, neredeyse bütün Anadolu'ya hizmet etmiştir (Serçe 2010, 27, 28). Kavala'da da, benzer gelişmeler yaşanmış, kent ve bölgesinde hastanelerin ve okulların açılması, pek çok liman kentinde olduğu gibi, yeni bir kentlilik biçimine işaret eden, eğitim ve sağlık hizmetlerinin gelişimini ortaya koymuştur (Arslan 2009, 299, 300) (Şekil 2).

Öte yandan, söz konusu kentlerde demografik yapıdaki çeşitlilik, farklı coğrafyaların mimari biçim ve üsluplarını da beraberinde getirmiştir. Örneğin, Abulafia'ya göre $(2012,655)$ külttürlerin karşılaşıp karıştığı bir kent olan İskenderiye'deki Mısır Merkez Bankası, Mısır'da doğmuş ve İtalya'da eğitim görmüş mimar Alessandro Loria tarafından yapılmış, bir Venedik Palazzo'suna benzemektedir. Ancak kentte, farklı üsluplarda 


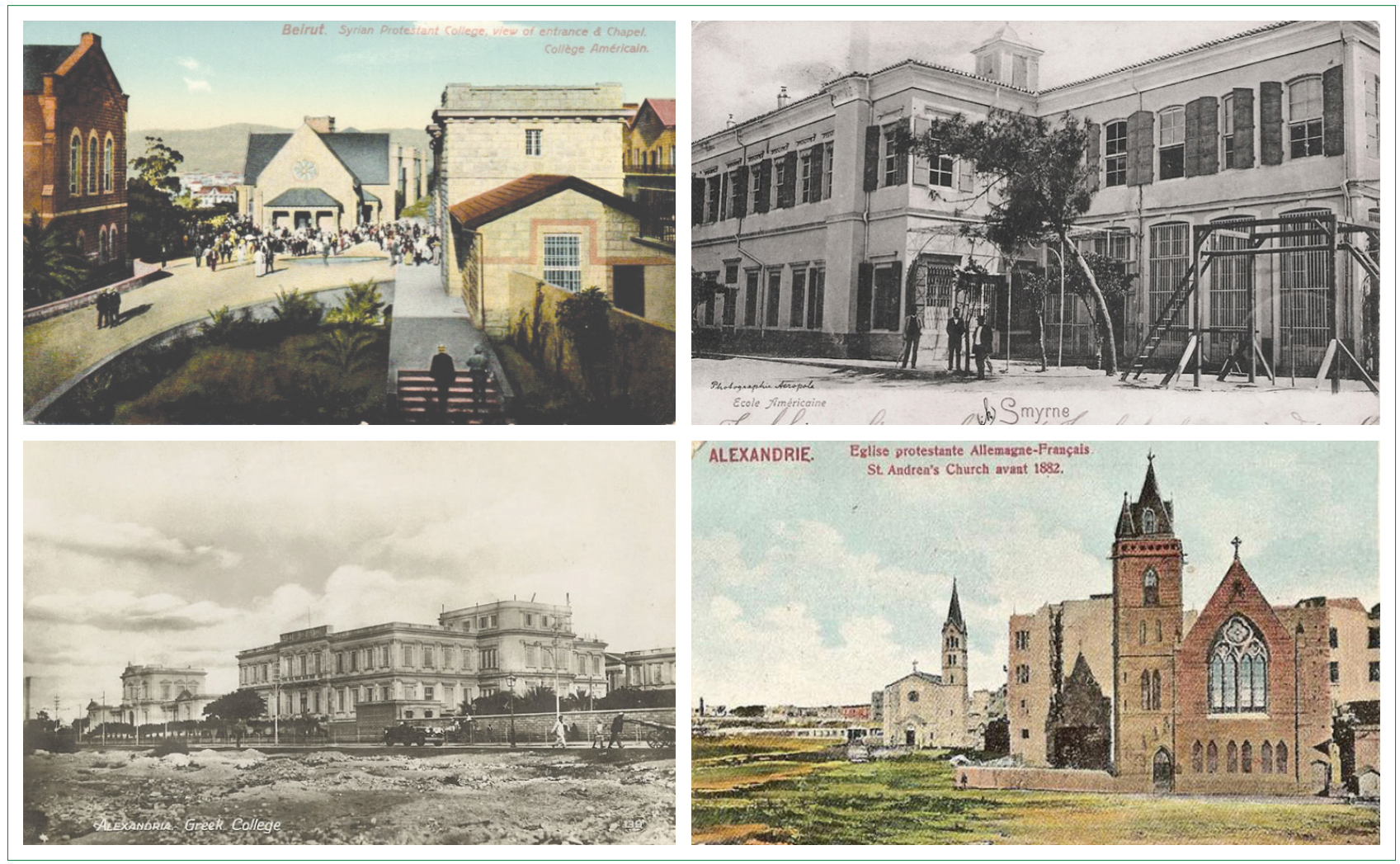

Şekil 2. Beyrut Amerikan Koleji, İzmir Amerikan Okulu, İskenderiye Greek College, İskenderiye Alman-Fransız Protestan Kilisesi (Kaynak: http://oldbeirut.com/post/I55386553708/american-university-of-beirut-1910s, http://www.levantineheritage.com/college.htm, http://www.levantineheritage. com/alexandria.htm, http://www.levantineheritage.com/alexandria.htm).

inşa edilmiş, Yahudi ve İtalyan hastane yapılarının yer aldığı tertemiz sokakların yanı sıra Rum, İtalyan, Yahudi ve Kıpti nüfusun yaşadığı kentin kuzey kıyılarında farklı bir kentsel doku ve yaşam söz konusudur (Abulafia, 2012, 655, 656). ${ }^{3}$

Selanik'te, Hıristiyan, Yahudi ve Müslüman gruplar farklı mahallelerde ve Ortaçă̆ kentinin sınırları içinde kendi içine dönük biçimde yaşarken, on dokuzuncu yüzyıldaki ticari gelişmeyle birlikte, kentsel mekan değişmeye başlamış, surların dışına doğru genişleyen kentte, ortaya çıkan burjuvazi kentin dışında yeni banliyölerde yaşamaya başlamıştır (Hastaoglou-Martinidis 1997, 494). Dolayısıyla, demografik yapının bileşenlerinin kendi içlerindeki kapalı yaşamı yerini sınıfsal bir ayrışmaya bırakırken, söz konusu ayrışma kentsel mekanda da görünür hale gelmiştir. Söz konusu değişim, yeni bir kentsel mekan organizasyonunu getirmiş, yaya ve hayvanlarla sağlanan ulaşıma, şehirlerarası ve hatta şehir içinde demiryolu ulaşımı eklenmiştir.

\section{Ulaşım Altyapısına Yönelik Yatırımlar ve Kentsel Mekanın Gelişimi}

Kapitalizmin sınır ötesi mekansal örgütlenme gereksinimi ile mal aktarımını hızlandırmak ve karlılığı artırmaya yönelik olarak bu kentlerde, özellikle 1850 'li yıllardan itibaren başlayan demiryolu, karayolu, iskele, rıhtım, liman gibi ulaşım altyapısına yönelik yatırımlar hız kazanmıştır. Bu doğrultuda liman kentlerinde, özellikle yabancı girişimciler tarafından, bu kentleri art bölgesindeki verimli ovalara bağlayan, etkin ve ucuz bir erişim aracı olarak demiryolları yapılmıştır (Şen 200।, 95, 96). Söz konusu kentler, özellikle demiryolları ağı ile sanayileşmiş merkez ülkelerle bağlandığı gibi aynı zamanda, art alanlarındaki tarımsal üretim bölgeleriyle ve iç kesimlerle de bağlanmıştır (Kurmuş 2012; Hastaoglou-Martinidis 2010).

Bu dönemde demiryollarının söz konusu yapım amaçlarına en iyi ve somut örnek İzmir-Aydın demiryoludur (Aktüre 1978, 74). On dokuzuncu yüzyııın ikinci yarısında, büyük ölçekli projelerden biri olarak söz konusu demiryolunun inşası, demiryolu ağının kente girişi ve iki önemli gar yapısı ile İzmir'in mekansal kurgusunu büyük ölçüde değiştirmiştir. Yapıldığı dönemde kentsel alanın dışında inşa edilen Aydın Garı, kentsel gelişmeyi kuzeye doğru çekerek, merkez işlevinin bu yöne kaymasında etkili olmuş, kent merkezinin doğusunda inşa edilen Kasaba Garı ise liman ve Basmane arasında yük trafiği yaratmış ve bu

Abulafia $(2012,656)$, İskenderiye'de yabancı toplulukların gündelik yaşamının ticari yaşamda ve kafelerde geçtiğini ifade etmektedir. Dolayısıyla, kentin demografik yapısındaki çeşitliliğin, liman kentlerinde, kentsel mekandaki bir diğer yansıması da kafe, lokanta, kulüp gibi çeşitli, sosyo-kültürel kullanımlardır. Bunun örneklerine, özellikle sahilde yer alan otelleri, restoranları, kafe, sinema, tiyatro, kulüp gibi yapıları ile Beyrut, İzmir, Selanik gibi liman kentlerinde de sıklıkla rastlanmaktadır. 


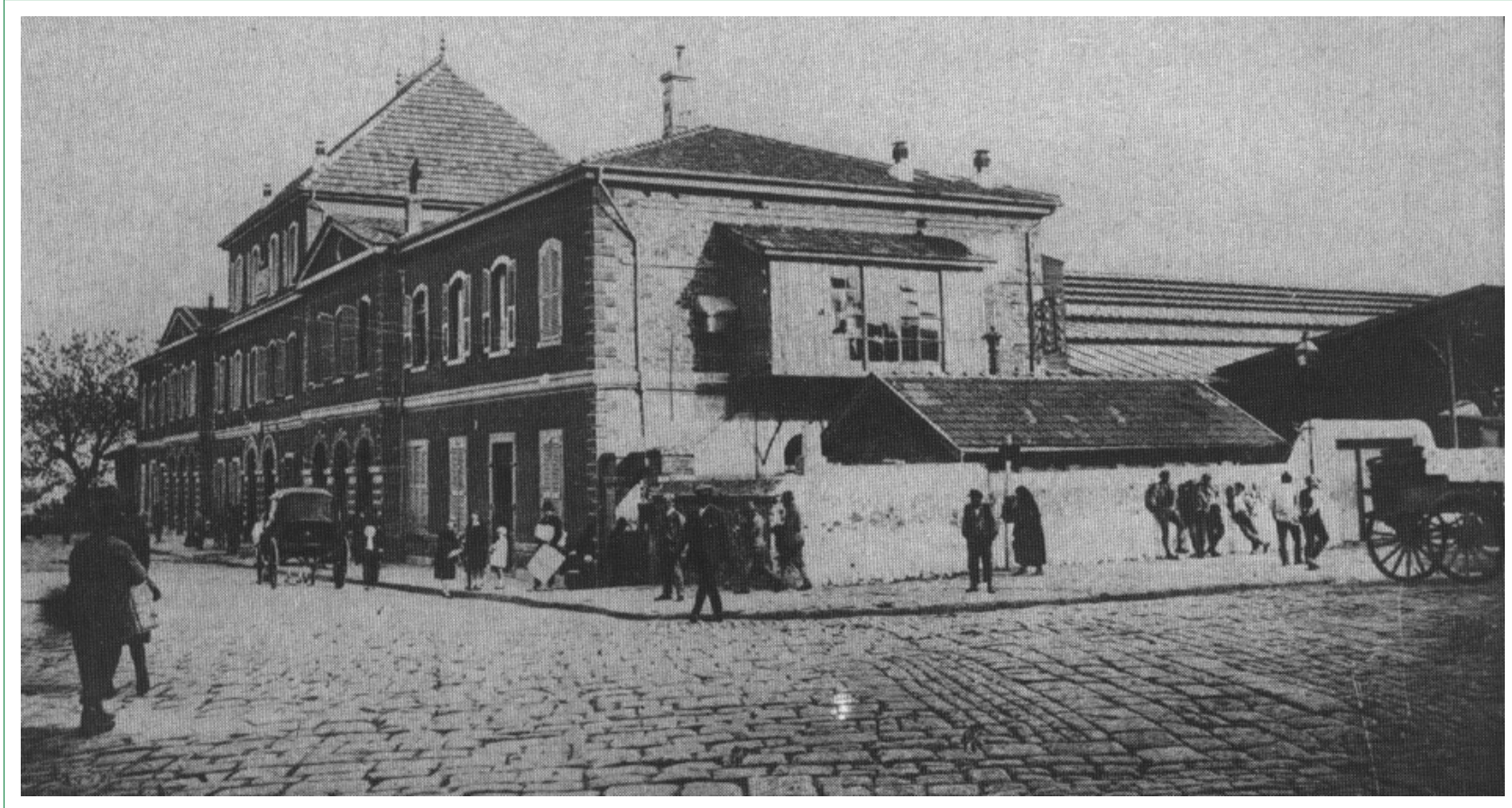

Şekil 3. İzmir Basmane Garı (Kolay, 20II).
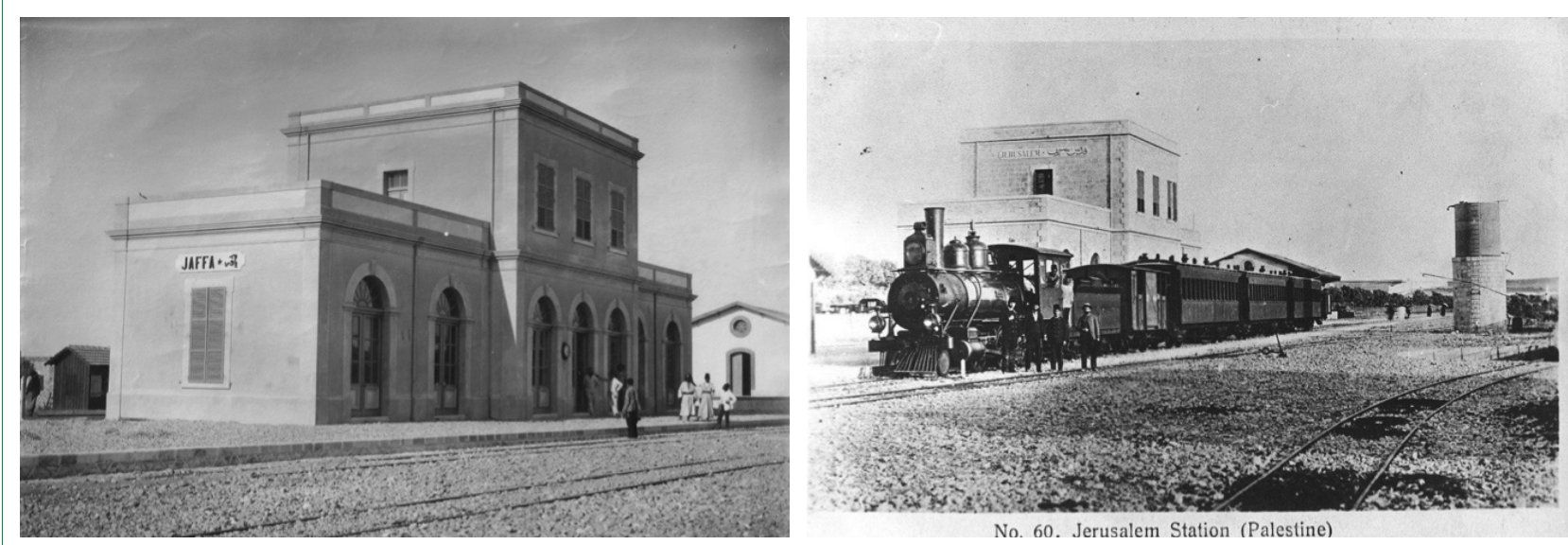

No. 60. Jerusalem Station (Palestine)

Şekil 4. Yafa Tren İstasyonu (Kaynak: https://image.jimcdn.com/app/cms/image/transf/none/path/sf803 Ic25d20e8688/image/i9bf4d826bb8ed729/ version/I39|486477/image.jpg, ve https://www.flickr.com/photos/I24446949@N06/20638820272, Erişim tarihi: I3 Kasım 2018).

nedenle bu iki nokta arasında yeni bir cadde açılmıştır (Bilsel 2000, 35, 36) (Şekil 3).

Ege Bölgesi'ni İzmir'e bağlayan İzmir-Aydın hattı gibi Mersin-Adana demiryolu da Çukurova Bölgesi'ni Mersin'e bağlamıştır. Çünkü tarımsal üretim açısından oldukça zengin bir bölge olarak Çukurova, önemli bir hammadde ve pazar alanıdır. Malların aktarım noktası olarak Mersin'i Çukurova'ya bağlayan demiryolu için $1860^{\prime}$ 'l yıllarda başlayan girişimler sonuç vermiş ve Mersin-Adana demiryolu hattı 1886 yılında hizmete girmiştir (Dingeç 1998, 19). Söz konusu demiryolu inşası, $1890^{\prime}$ 'ı yıllara gelindiğinde Mersin'in, Anadolu'nun önemli bir aktarım noktası haline gelmesini ve gelişmesini sağlamıştır (Selvi Ünlü 2007, 107).

Mersin-Adana ilişkisinde olduğu gibi, Yafa-Kudüs ilişkisi de demiryolu bağlantısı ile güçlenmiştir. Avcı (2015 39I, 392), özellikle on dokuzuncu yüzyılın son çeyreğinde, Beyrut ve İskenderiye gibi Doğu Akdeniz'deki diğer liman kentleri kadar Yafa için de büyük bir ticari hareketlenme dönemi olduğunu belirterek, Yafa'nın Kudüs sancağının başlıca limanı olmasının ticaretin gelişimini sağlayan asıl etken olduğunu ve 1892 yılında Kudüs-Yafa arasında inşa edilen demiryolu hattının kentin bu işlevini daha da güçlendirdiğini dile getirmiştir (Şekil 4). 

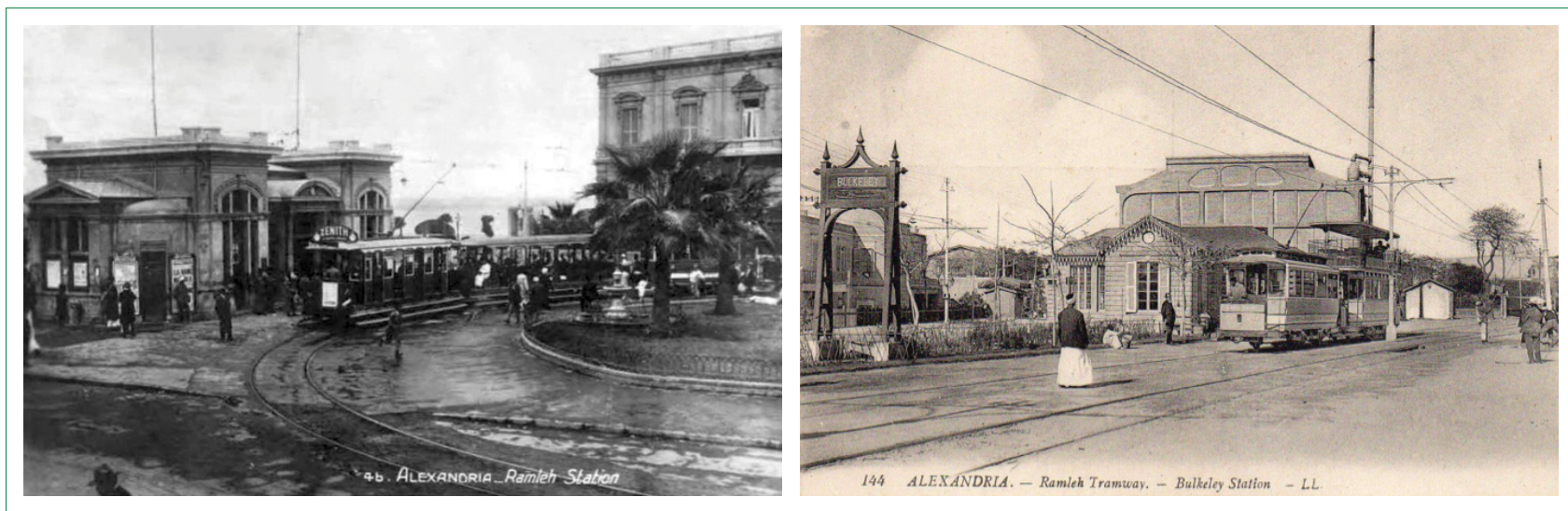

Şekil 5. http://cairobserver.com/post/3053I43।8II/on-cairos-dying-trams\#.XFGRKi2B27M, ve https://i.pinimg.com/originals/26/88/49/2688493 224795 I bf447fe67f5503f0f2.jpg, Erişim Tarihi: 30 Ocak 2019).

I87I yılında inşa edilen ve Selanik'i Mitroviç'e bağlayan ilk demiryolu hattı da benzer biçimde, kentin Avrupa'yla doğrudan bağlanmasını sağlayan önemli bir yatırım olarak kent için, yalnızca ekonomik değil, artan liman faaliyetiyle birlikte, limanın genişletilmesi, gümrük binasının onarımı gibi çeşitli fiziksel değişiklikleri beraberinde getirmiştir (Gounaris 1994). 1854 yılında inşa edilen demiryolu hattı ile Kahire'ye bağlanan İskenderiye ise Mısır'da üretilen pamuğun diğer ülkelere aktarıldığı bir kapı niteliğini kazanmış, 1854-1890 yılları arasındaki dönem, kentin gelişimindeki önemli aşamalardan biri olmuştur (Abdel-Salam 1995, 183; Barak 2009, 189). Artan liman etkinliği ve ticaretle birlikte çevreden yönelen göçle, kentin çevresinde yeni yerleşimler gelişmiş ve bu yeni yerleşimler ile bağlantı sağlayan demiryolu hatları inşa edilmiştir. Örneğin 1860 yılında, doğudaki El-Ramleh banliyo yerleşimi ile kent arasında inşa edilen demiryolu hattı, özellikle doğudaki yerleşimlerin çekiciliğini artırmış ve bu hızlı yayılma sonunda söz konusu hat 1904 yılında elektrikli tramvaya dönüştürülmüştür (AbdelSalam 1995, 183). Öte yandan, 1876 yılında, doğu limanının güney tarafında, yolcular için yeni bir demiryolu istasyonu inşa edilmiş, eskisi yalnızca nakliye istasyonu olarak kullanılmaya başlanmış, antrepolar, fabrikalar ve kereste depoları bunun çevresinde yer almıştır (Abdel-Salam 1995, 183) (Şekil 5).

Benzer biçimde, on yedinci yüzyıldan itibaren Filistin ve Avrupa ile gelişen ticari ilişkilerle ve artan üretim çeşitliliği ile bir ticari merkez haline gelen Hayfa da, on dokuzuncu yüzyılda, Şam-Hayfa Demiryolu'nun yapımıyla, tarihi merkezin ve surların dışında yeni konut alanlarının gelişimiyle büyümüştür (Carmel 20I I, I3, 4I; Kolodney ve Kallus 2008, 328). Öyle ki, Hicaz Demiryolu'nun yapımı sonrasında, Doğu Akdeniz'in en büyük rafinerisi kentte yer almış, bataklık alanların kurutulması ile Hayfa, limanla bütünleşik bir sanayi kenti haline gelmiştir (Amiran ve Shahar 1961, 363).

Demiryollarının yanı sıra yeni karayolu bağlantıları da söz konusu kentlerin mekansal gelişiminde etkili olmuştur. Örneğin
Şam yolunun yapımı, Beyrut'un özellikle tarihi kent merkezinin uç kesimlerinin gelişimini hızlandırmış ve bunu, limanı ticari merkeze ve kentin meydanını kentin giriş kapısına bağlayan iki büyük arterin açılması izlemiştir (Çelik 20।2, I25).

Dolayısıyla, ulaşım altyapısına yönelik yatırımlar ve özellikle demiryollarının inşası, Doğu Akdeniz liman kentlerinin liman işlevini güçlendirip ticari kapasitesini artırmakla kalmamış, aynı zamanda kentsel mekanın biçimlenişinde de belirleyici rol oynamıştır. Liman ve istasyon arasındaki bağlantı, bu kentlerin mekansal kurgusundaki ana ticari hattı oluştururken, kentsel mekana eklenen istasyon binaları, depolama alanları, sanayi işletmeleri gibi yeni yapı ve kullanımlar kendini göstermiştir. Öte yandan, artan ulaşım olanağı, erişilebilirliği artırarak kent çevresinde yeni konut alanları ve yerleşimlerin gelişmesinin yolunu açmış, pek çok kentte, raylı sistemin kentiçi ulaşımda da kullanılmasını beraberinde getirmiştir (Tekeli 1985, 882; Yeralympos 1999, 49).

Böylece, demiryolu, karayolu gibi yeni ulaşım olanakları, kentsel yerleşik alanın genişleyip yayılmasında, kentlerin etrafında, Selanik ve Hayfa'da olduğu gibi surların dışında yeni konut alanları ve banliyölerin oluşmasında etkili olmuştur. Bu da beraberinde, çeşitlenen kentsel hizmetlerle büyüyen kentsel yerleşik alanla birlikte nüfus artışını getirmiş, farklı bölgelerden gelen nüfus ve ticari etkinliğin gerektirdiği iletişim ve haberleşmeye yönelik yatırımlar da kendini göstermeye başlamıştır. Artan iletişim gereksinimi doğrultusunda, pek çok liman kentinde telgraf hatları kurulmuş, telgraf ağının İmparatorluğun her köşesine ulaşması sağlanmıştır (Gül 20।3, 77). Örneğin Volos, 1863 yılında telgraf hattı ile Selanik'e bağlanmış ve kale ile yeni gelişen şehir arasındaki ticaret meydanında bir telgraf ofisi açılmıştır (Hastaoglou-Martinidis 2004, 52). I868 yılında, Adana'dan Tarsus'a kadar döşenen telgraf hattının Mersin iskelesine dek uzatılmasına karar verilmiş ve 1873 yılında kentte, bir telgraf ve posta idaresi kurulmuştur (Selvi Ünlü 2007, I72-I74) (Şekil 6). 


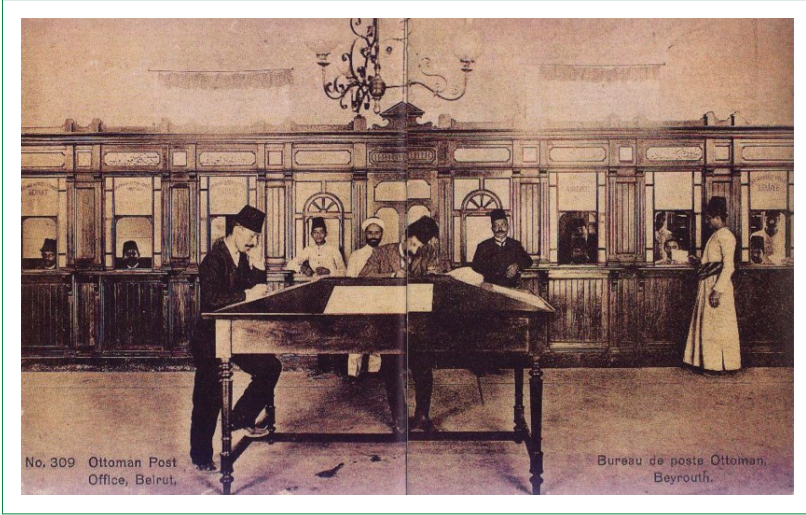

Şekil 6. Beyrut Posta Ofisi (Kaynak: http://almashriq.hiof.no/lebanon/700/760/769/old_beirut/Ottoman_Post_Office.jpg, Erişim Tarihi: 30 Ocak 2019).

\section{Kurumsal Yapının Değişimi ve Kentsel Mekanın Gelişimi}

Temelde deniz ticaretine dayalı bütün bu gelişmelerin yanı sıra, Doğu Akdeniz liman kentlerinin pek çoğu, Osmanlı'nın modernleşme çabalarının kurumsal yapıda yarattığı değişimlerin de öncelikli ve somut olarak görüldüğü yerler olmuştur. Çünkü bu kentlerde, özellikle tüccarlar tarafından, ticari kazancı yükseltme, işgücünün verimliliğini artırma gibi hedefler doğrultusunda daha sağlıklı bir çevre ve kentsel altyapıya yönelik talepler, yerel yönetim kurumlarının oluşturulmasında etkili olmuştur. Bu da, yerel yönetim kurumlarının, liman kentlerinde diğer Anadolu kentlerine göre çok daha erken gelişmesini sağlamış, 1864 Vilayet Nizamnamesi'ndeki maddelere dayanarak, özellikle dış ticaretin yoğun olduğu bu kentlerde, hızla belediyeler kurulmuştur (Yenişehirlioğlu vd. 1995, 21). 1860'lı yıllardan itibaren, belediye meclisleri ve belediyelerin kurulması, gerek söz konusu yapıların kentsel mekanda yerini alması ve gerekse, artık kentin gelişiminde söz sahibi olacak bir kurumsal yapının oluşturulması, bu kentlerde önemli değişimler yaratmıştır (Tekeli 1985, 882).

Örneğin 1868 yılında İzmir'de, kentin nüfus bileşenlerinin tümünün temsil edildiği bir belediye meclisi kurulurken (Bilsel 2008, I58), bir ticaret odağı haline gelen İskenderiye'de, yaşayan Avrupalı tüccarlar, bakımsız ve altyapıdan yoksun yolları, masrafları kendileri karşılayarak yeniden düzenlemişler ve Avrupalı tüccarlar tarafından başlatılan girişimler, İskenderiye Belediyesi'nin kurulması yolunda atılan ilk adımlar olmuştur (Barak 2009, 190). Kentsel mekanın iyileştirilmesine ilişkin yerel taleplerle birlikte 1885 yılında kurulan belediye, İskenderiye'de kornişin inşası, büyük park ve bahçelerin açılması, surların yıkılması, yoksul mahallelerin yeniden düzenlenmesi gibi pek çok uygulama ile kenti, Avrupa tarzı bir şehircilik anlayışıyla yeniden şekillendirmiştir (Ilbert 2006b, 3I).

Bu dönemde belediye kurulan bir başka liman kenti de Beyrut olmuştur. 1860 yılında kurulan belediye, kentte kamusal mekanları düzenlemiştir (Nasr ve Verdeil 2008, III9). I860’larda Tanzimat reformlarının uygulandığı bir diğer liman kenti Selanik'te de, 1869'da belediyenin kurulmasının ardından, yeni bir liman projesi hazırlanmış, yıkılan kent surlarının bulunduğu bölgede yeni bir konut bölgesi oluşturulmaya çalışılmıştır (Yerolympos 1996, 62). Aynı tarihte, Mersin'de de belediye meclisi kurulmuştur (Selvi Ünlü 2007, 77).

İdari yapıda yaşanan değişimle birlikte, bir yandan kentsel mekana belediye meclisleri, yapı ve sokak komisyonları, belediye gibi yeni yapı ve kullanımlar eklenmiş ve bir yandan da, kentte daha önce olmayan bir idari merkez şekillenmiştir. Örneğin Yafa'da, 1897 yılında kent sakinlerinin ve eşrafın katkılarıyla inşa edilen hükümet konağı, askeri kışla, belediye binası ve diğer yönetim yapıları kentin yeni idari merkezini oluşturmuştur (Avcı 20I5, 389). Benzer biçimde Mersin'de de, kıyıya paralel cadde, ticari etkinliğin merkezi olduğu gibi hükümet konağı, belediye gibi yapıların yer aldığı idari merkez olarak gelişmiştir (Selvi Ünlü 2007, 163).

\section{Sonuç}

Bütün bu örnekler dikkate alındığında, on dokuzuncu yüzyılın özellikle ikinci yarısından itibaren, Doğu Akdeniz'de değişen üretim biçim ve ilişkileri ile çoğunlukla doğal liman işlevi ve art alanlarındaki verimli topraklar ve tarımsal üretim olanaklarına sahip avantajlı coğrafi konumlarıyla bu kentlerin kendine özgü bir kentsel yapı ile şekillendiği görülür. Ilbert (2006b) bu kentlerin, toplumsal yapıları, farklı kültür, inanç ve dilleri buluşturan yaşam biçimleri ile Doğu'da “kendine özgü bir Batı” olarak daima ilgi çektiğini, nüfus ve yerleşim alanı büyüklüğünden bağımsız olarak, sahip oldukları kentli yaşam biçimi, sınıfsal ayrışma ve eski-yeni karşıtlığı nedeniyle barındığı çelişkilerle zengin bir araştırma alanı sunduğunu söylemiştir.

Örneklere bakıldığında Doğu Akdeniz liman kentlerinin mekansal gelişimindeki benzerliklerin, her bir kent için, kendi ekonomik, toplumsal ve kültürel bağlamı içinde farklılıklar taşıdığı görülmektedir. Ancak yine de, en azından burada ele alınan örnekler dikkate alındığında, Doğu Akdeniz liman kentlerinin, ticari ve idari açıdan görece özerk oldukları (Keyder ve diğer. 1994) on dokuzuncu yüzyılın özellikle ikinci yarısından, yirminci yüzyılın başına kadarki süreçte, kentsel mekandaki değişimlerin temel olarak deniz ticareti ve liman işlevinden ivme aldığı görülmektedir. Öte yandan, demiryolu ve karayolu gibi büyük yatırımlar da bu aşamada, Doğu Akdeniz liman kentlerindeki mekansal yapının şekillenmesinde etkili olmuştur. Söz konusu ulaşım yatırımları, bir yandan ticari kapasiteyi artırırken öte yandan, kentsel mekana demiryolu istasyonu gibi yeni yapıları eklemiş, kentsel mekan çoğunlukla liman-demiryolu istasyonu ilişkisi doğrultusunda şekillenmiş, artan ulaşım olanakları, kentin çeperinde yeni yerleşim alanlarının gelişimini hızlandırmıştır. Böylece ticari 
Tablo I. On dokuzuncu yüzyılda Doğu Akdeniz liman kenti ortak yapısal özellikleri ve mekansal karşılıkları

\begin{tabular}{|c|c|}
\hline Ortak yapısal özellikler & Mekansal karşıııkları \\
\hline Coğrafi konum (denizle ilişki) & Denizi referans alan mekansal kurgu \\
\hline \multirow[t]{10}{*}{ Liman işlevinin gelişimi } & İskele \\
\hline & Rıhtım \\
\hline & Mendirek \\
\hline & Dalgakıran \\
\hline & Deniz feneri \\
\hline & Depo \\
\hline & Antrepo vb. yapılar \\
\hline & Demiryolu (limana bağlanan) \\
\hline & Limana açılan ana cadde \\
\hline & Ana cadde ile ilişki içinde demiryolu istasyonu \\
\hline \multirow[t]{8}{*}{ Ticaret-finans sektöründe gelişme } & Banka şubeleri \\
\hline & Sanayi işletmeleri \\
\hline & Konsolosluklar \\
\hline & Kentsel mekanda sınıfsal farklılaşma \\
\hline & Yeni konut alanları ve mimari biçimler \\
\hline & Sosyo-kültürel kullanımlar (sinema, park, bahçe, kulüp, müze, kütüphane vb. yapı ve kullanımlar) \\
\hline & Gazeteler (matbaalar) \\
\hline & Postaneler \\
\hline \multirow[t]{5}{*}{ Nüfus artışı ve demografik yapıda çeşitlilik } & Eğitim kurumları \\
\hline & Dini yapılar \\
\hline & Sağlık yapıları \\
\hline & Genişleyen kentsel yerleşik alan \\
\hline & Yeni ulaşım biçimleri (tramvay) \\
\hline \multirow[t]{3}{*}{ Ulaşım bağlantılarının güçlenmesi } & Demiryolu ve ilgili kullanımlar (istasyon binaları, ilgili atölyeler) \\
\hline & Artan erişilebilirlikle yayılan kentsel alan (banliyöler) \\
\hline & Tramvay \\
\hline \multirow[t]{3}{*}{ Kurumsal yapının gelişimi } & Yeni idari yapıların inşası (hükümet konağı, belediye) \\
\hline & Yönetim merkezinin gelişimi \\
\hline & Parklar, bahçeler, yollar vb. kentsel altyapı yatırımları ve kullanımları \\
\hline
\end{tabular}

kapasitesi giderek artan söz konusu kentlerde, finans sektöründeki gelişmelere paralel olarak banka şubeleri açılmış, çeşitlenen ticari faaliyetlerle birlikte kentsel mekanda, farklı iş kollarında hizmet veren işletmeler, atölye, depo, antrepo gibi kullanımlar kendini göstermiştir.

Bu aşamada, özellikle tarımın ticarileşmesi ve hatta zaman içinde sanayileşmenin erken evrelerinin yaşanmasıyla gelişen burjuvazi, yeni tüketim alışkanlıkları ve yaşam biçimini üretmiş, bu da kentsel mekanın biçimlenişinde etkili olmuştur. Bu dönemde söz konusu kentlerde, farklı nüfus gruplarının birlikte ürettiği kentli yaşam biçimi ve sınıfsal farklılaşmaya dayalı bir mekansal yapı gelişmiş, özellikle ticaret burjuvazisi ve yeni yönetici sınıfa ait konut bölgeleri, mahalleler ve tarihi kentin dışında yerleşim alanları gelişirken, işçi sınıfının yaşadığı alanlar belirginleşmiştir.

On dokuzuncu yüzyılda, liman kentinin temel mekansal bileşenlerinden biri olan ve ticari etkinliğin sürdüğü kıyı şeridi de, söz konusu yeni yaşam biçimi doğrultusunda şekillenmiş, pek çok Doğu Akdeniz liman kentinde, özellikle üst gelir gruplarına ait konut alanları, gezinti ve yürüyüş yolları ile kıyı şeridi, liman kentinin en önemli kamusal mekanlarından biri haline gelmiştir. Öte yandan, sosyal yapının niteliği kadar büyüklüğündeki değişim de kentsel mekanda değişim yaratmış, kentsel yerleşik alan genişlemiş ve farklı nüfus gruplarının varlığının bir yansıması olarak kentsel mekana, farklı inançlara ait dini yapılar, farklı nüfus gruplarının eğitim ve sağlık yapıları eklenmiştir. Yeni tüketim alışkanlıkları ve kentli yaşam biçimin mekansal karşılıkları olarak, restoran, kafe, kulüp, spor alanları, müze, kütüphane gibi sosyal ve kültürel yaşama yönelik yeni yapı ve kullanımlar da bu aşamada kentsel mekandaki yerlerini almıştır (Tablo I).

Dolayısıyla, on dokuzuncu yüzyılda Doğu Akdeniz liman kentinin, sosyal ve mekansal yapıda görülen çeşitlilikle, kapitalist ekonomik ilişkiler ve yerelin gereksinimleri doğrultusunda, temel olarak denizle ilişkiye dayalı bir kentsel yapı ile şekillendiği izlenmektedir. Bu da, söz konusu kentlerin, toplumsal olarak üretildiği ve herhangi bir plana dayanmadan, kendiliğinden (spontaneous) gelişen bir doku ile farklı kullanımların bir arada olduğu kendine özgü bir kentsel yapıyla geliştiğine 
işaret etmektedir (Leontidou, 2006, 7-I I). Söz konusu ortak yapısal özellikler ve benzer süreçler bu kentlerin, yakın coğrafyalarında yer alan iç kesimlerdeki kentlerden çok, uzaktaki bir başka liman kentiyle taşıdığı benzerliği de belli ölçüde açıklamaktadır. Elbette söz konusu süreçte yere özgü farklılıklar kaçınılmazdır. Bu nedenle, bu çalışmanın sınırları içinde esas alınan değerlendirme başlıkları doğrultusunda, gerek Doğu Akdeniz liman kentleri arasındaki farklılıkların ve gerekse, Doğu Akdeniz liman kentinin Akdeniz'in batısındaki diğer liman kentleri ile benzerlik ve farklılıklarının ortaya konularak araştırılması ve sorgulanması, alana ilişkin çalışmalara önemli katkı yapacaktır.

\section{KAYNAKLAR}

Abdel-Salam, H. (1995) “The historical evolution and present morphology of Alexandria, Egypt", Planning Perspectives, 10 (1995), 173-198.

Abulafia, D. (2012) Büyük Deniz Akdeniźde İnsanlık Tarihi, (çev.) Gül Çağalı Güven, İstanbul: Alfa Tarih. (The Great Sea A Human History of the Mediterranean, 2011)

Akkaya, Y. (1998) “19. Yüzyılın Sonunda Selanik'te Sanayileşme ve Ücretli Emek", Ekonomik Yaklaşım, Cilt 9, Sayı 31, 25-35.

Aktüre, S. (1978) 19. yüzyıl sonunda Anadolu kenti mekansal yapı çözümlemesi. Ankara: ODTÜ Mimarlık Fakültesi Baskı Atölyesi.

Akyalçın Kaya, D. (2015) “Mustafa Arif Efendi’nin Selanik Yılları: XIX. Yüzyıl Osmanlı Taşrasında Burjuvazinin Oluşumuna Bir Örnek", Cihannüma Tarih ve Coğrafya Araştırmaları Dergisi, Sayı I/2, 39-59.

Alpaslan, İ. (2012) “Osmanlı Dönemi İzmir' inde Milletlerin Sosyo-Ekonomik Konumlarındaki Değişimin Yerleşim Dokusuna Etkileri”, Aegean Geographical Journey, Vol. 21(2), 25-35.

Amiran, D., \& Shahar, A. (1961) The Towns of Israel: The Principles of Their Urban Geography. Geographical Review, 51(3), 348-369.

Anastassiadou, M. (2014) Tanzimat Çağında Bir Osmanlı Şehri Selanik (1830-1912), İstanbul: Tarih Vakfi Yurt Yayınları.

Arslan, İ. (2009) 19. Yüzyllda Balkanlarda Sosyo-Ekonomik İlişkiler: Drama Sancağı Örneği (1864-1913), Yayımlanmamış Doktora Tezi, Ege Üniversitesi Sosyal Bilimler Enstitüsü, Tarih Ana Bilim Dalı.

Avc1, Y. (2015) “19. Yüzyılın Son Çeyreğinde Filistin’in Limanı Yafa”, Tarih İncelemeleri Dergisi, XXX / 2, 385-411.

Barak, O. (2009) "Scraping the surface: the techno-politics of modern streets in turn-of-twentieth-century Alexandria", Mediterranean Historical Review, Vol. 24, No. 2, 187-205.

Barakat, L. B. (2004) “Beirut: A city with so many faces". Dela, 21, 485-493.

Beyru, R. (2011) 19. yüzyllda İzmir kenti. İstanbul: Literatür.

Bilsel, C. (2000) “19. Yüzyılın İkinci Yarısında İzmirde Büyük Ölçekli Kentsel Projeler ve Kent Mekanının Başkalaşımı”, İzmir: Ege Mimarlık, 2000/4, 34-37.

Bilsel, C. (2008) Modern bir Akdeniz metropolüne doğru. M. C. Smyrnelis, (Ed.), İzmir 1830-1930: Unutulmuş bir kent mi? Bir Osmanlı Limanından Hatıralar içinde (143-160). İstanbul: İletişim.

Bilsel, C. (2009) “İzmir'de Cumhuriyet Dönemi Planlaması (1923-1965): 20. Yüzyıl Kentsel Mirası", İzmir: Ege Mimarlık, 2009/4, 12-17.

Carmel, A. (2011) Ottoman Haifa-A History of Four Centuries Under Turkish Rule, I. B. Tauris, London, New York.

Çelik, Z. (2012) İmparatorluk, Mimari ve Kent Osmanlı-Fransız Karşılaşmalar1 (1830-1914), İstanbul: SALT.

Dimoglou, A (2003) Kent ve Yerel Yönetim: Volos Belediyesi Örneği, 1881-

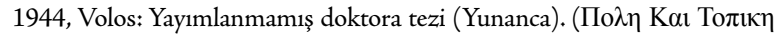

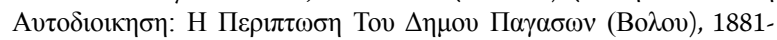
1944).

Dimoglou, A. ve Mourtzoukos, L. (2006) Volos then \& now. Atina: Olkos.

Dingeç, E. (1998) 19. yüzyılın ikinci yarısında ve 20. yüzyılın başında Mersin'in ekonomik yapısı. Yüksek Lisans Tezi, Anadolu Üniversitesi Sosyal Bilimler Enstitüsü.

Driessen, H. (2005) Mediterranean port cities: cosmopolitanism reconsidered. History and Anthropology, 14 (1), 129-141.

Frangakis-Syrett, E. (2001) The making of an Ottoman port: The quay of Izmir in the nineteenth century. Journal of transport history 22, no. 1 içinde (23-46).

Georgelin, H. (2008) Smyrnánın Sonu İzmir'de Kozmopolitizmden Milliyetçiliğe, İstanbul: Bir Zamanlar Yayıncllk.

Gounaris, B. C. (1994) Selanik. Ç. Keyder, Y. E. Özveren, D. Ouatert, (Ed.), Doğu Akdeniz liman kentleri (1800-1914) içinde (103-120). İstanbul: Tarih Vakfi Yurt Yayınları.

Hassoun, J. (2006) “Yahudiler, Bir Karşıtlıklar Cemaati”, Geçici Bir Hoşgörü 
Modeli Cemaatler ve Kozmopolit Kimlik İskenderiye 1860-1960, R. Ilbert, I. Yannakakis, J. Hassoun (eds.), İstanbul: İletişim Yayınları, 47-64.

Hastaoglou-Martinidis, V. (1997) "A Mediterranean city in transition: Thessaloniki between the two World Wars". The Scientific Journal FACTA Universitatis Series: Architecture and Civil Engineering, 1 (4), 493-507.

Hastaoglou-Martinidis, V. (2004) "Foundation and Evolution of the New City During the 19th Century", Volos 1881-1955 The City and The People, DIKI, Volos, 43-60.

Hastaoglou-Martinidis, V. (2007) Volos portrait of the city from the 19th to

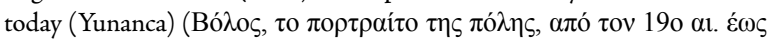
$\sigma \eta ́ \mu \varepsilon \rho \alpha)$. Volos: DIKI (Volos Tarihi Araştırma ve Dokumantasyon Mer-

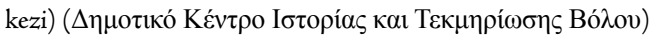

Hastaoglou-Martinidis, V. (2010) "The cartography of harbor construction in eastern Mediterranean cities: technical and urban modernization in the late nineteenth century". M. Toksöz ve B. Kolluoğlu, (Ed.), Mapping out the Eastern Mediterranean: toward a cartography of cities of commerce, cities of the Mediterranean from the Ottomans to the present day içinde (7899). London, New York: I.B. Taurus.

Gül, M. (2013) Modern İstanbul'un doğuşu bir kentin dönüşümü ve modernizasyonu. İstanbul: Sel.

Ilbert, R.; Yannakakis, I.; Hassoun, J. (2006a) Geçici Bir Hoşgörü Modeli Cemaatler ve Kozmopolit Kimlik İskenderiye 1860-1960, İstanbul: İletişim Yayınlar1.

Ilbert, R. (2006b) “Dünyaya Açık Bir Akdeniz’ in Simgesi”, Geçici Bir Hoşgörü Modeli: Cemaatler ve Kozmopolit Kimlik İskenderiye 1860-1960, Ilbert, R.; Yannakakis, I.; Hassoun, J. (yay. haz.), Dünya Şehirleri Dizisi 9, İstanbul: İletişim Yayınları, 9-15.

Ilbert, R. (2006c) “Bir Kentlilik Biçimi”, Geçici Bir Hoşgörü Modeli Cemaatler ve Kozmopolit Kimlik İskenderiye 1860-1960, R. Ilbert, I. Yannakakis, J. Hassoun (eds.), İstanbul: İletişim Yayınları, 19-44.

Karagiannakidou N. E.; Lykourinou K. (2005) Neapolis - Christoupolis -

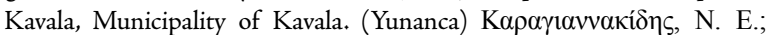

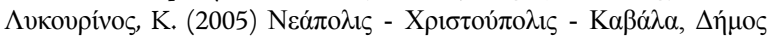
$\mathrm{K} \alpha \beta \alpha \dot{\lambda} \alpha \varsigma_{\text {. }}$

Keyder, Ç., Özveren, Y. E., Quatert, D. (1994) Osmanlı İmparatorluğu'nda liman kentleri bazı kuramsal ve tarihsel perspektifler. Ç. Keyder, Y. E. Özveren, D. Ouatert, (ed.), Doğu Akdeniz liman kentleri (1800-1914) içinde (121-155). İstanbul: Tarih Vakfi Yurt Yayınlar1.

Kolay, A. (2011) İzmir-Kasaba ve Uzantısı Demiryolu Hatları (1863-1897), Yayımlanmamış Doktora Tezi, İstanbul: Marmara Üniversitesi.

Kolluoğlu Kırlı, B. (2007) "Cityscapes and modernity: Smyrna morphing into İzmir". A. Frangoudaki ve Ç. Keyder, (ed.), Ways to modernity in Greece and Turkey içinde (217-235). London: I.B.Tauris.

Kolodney, Z., Kallus, R. (2008) “From colonial to national landscape: Producing Haifa's cityscape". Planning Perspectives, 23, 323-348.

Kurmuş, O. (2012) Emperyalizmin Türkiyéye giriși. (2. Baskı). İstanbul: Yordam.

Lalenis, K., Samourkasidou, E. (2013), “Wakfs In Kavala, Greece: A Legal, Political and Architectural Heritage Issue", International Journal of Architectural Research (Archnet-IJAR), Volume 7(2), 206-220.

Leontidou, L. (2006) The Mediterranean city in transition: social change and urban development. New York: Cambridge University Press.

Malcolm, W. ve Frangakis-Syrett, E. (1992) The port of Patras in the second Ottoman Period. Economy, demography and settlements c.1700-1830. Revue du monde musulman et de la Méditerranée Année, 66, 1, 79-94.

MP (2014) Haritalar ve hatıralar 1813-1943. Patras: Patras Belediyesi. (Yu-

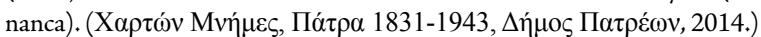

Nasr, J. ve Verdeil, E. (2008) The reconstructions of Beirut. S. K. Jayyusi, R. Holod, A. Petruccioli ve A. Raymond, (Ed.), The city in the Islamic world içinde (1116-1141). Leiden: Brill.

Özveren, Y. E. (1994) Beyrut. Keyder, Ç., Özveren Y. E., Ouatert D. (Ed.). Doğu Akdeniz liman kentleri (1800-1914) içinde (75-102), İstanbul: Ta- rih Vakfi Yurt Yayınları.

Reyhan, C. (2008) Osmanlı'da kapitalizmin kökenleri. İstanbul: Tarih Vakfi Yurt Yayınları.

Rentetzi, M. (2008) “Configuring Identities Through Industrial Architecture and Urban Planning: Greek Tobacco Warehouses in Late Nineteenth and Early Twentieth Century", Science Studies, 21(1), 64-81.

Selvi Ünlü, T. (2007) 19. yüzyılda Mersin'in kentsel gelişimi. Yayımlanmamış Yüksek Lisans Tezi, Mersin Üniversitesi: Mersin.

Selvi Ünlü, T. (2016) “On dokuzuncu yüzyıldan yirminci yüzylla doğu Akdeniz liman kentlerinde mekanın dönüșümü: Volos, Patras ve Mersin”. Yayımlanmamış Doktora Tezi, İzmir: Dokuz Eylül Üniversitesi.

Serçe, E. (2010) II. Meşrutiyet Döneminde İzmir, Değişen İzmir'i Anlamak, (der.) Yllırım, D., Haspolat E., Ankara: Phoenix, 23-41.

Soffer, A. ve Stern, S. (1986) The Port City: A Sub-Group of the Middle-Esatern City Model. Ekistics, 316, 102-106.

Stergiopoulos, D. (2016) "Tobacco Cultivation and Trade in Kavalla and the Ottoman Financial Policy: A Case of Financial Growth in the Late Ottoman Empire", Advances in Historical Studies, 5, 92-101.

Şen, L. (2001) "Merkez-Çevre İlişkilerinin Önemli Bir Dinamiği Olarak Osmanlı İmparatorluğu'nda Ulaştırma Sistemleri", Kebikeç İnsan Bilimleri İçin Kaynak Araştırmaları Dergisi, Kebikeç Yayınları, sayı: 11, Ankara, s.95, 96, s.s. 124 .

Tekeli, İ. (1985) “Tanzimat'tan Cumhuriyeté Kentsel Dönüşüm”, Tanzimat'tan Cumhuriyete Türkiye Ansiklopedisi, İstanbul: İletişim Yayınları, 1985, c.4, 878-890.

Trimi, K. (2006) “Yunanlılar: İskenderiyénin ‘Parikia’sı", Geçici Bir Hoşgörü Modeli Cemaatler ve Kozmopolit Kimlik İskenderiye 1860-1960, R. Ilbert, I. Yannakakis, J. Hassoun (eds.), İstanbul: İletişim Yayınları, 77-87.

Yenişehirlioğlu, F. ve Hacettepe Üniversitesi Sanat Tarihi Bölümü Öğretim Üyeleri (1995) Mersin Evleri. Ankara: Kültür Bakanlığı.

Yerolympos, A. (1996) Urban transformations in the Balkans (1820 - 1920): Aspects of Balkan town planning and the remaking of Thessaloniki. Thessaloniki: University Studio Press.

Ylldız, Ö.(2018) "Sea Trade in Kavala Harbour at the Beginning of 20th Century", Tarih ve Günce, 1/3, 217-250.

Zandi-Sayek, S. (2012) Ottoman İzmir The Rise of a Port, 1840-1880, Minneapolis, London: University of Minnesota Press. 